\title{
Effects of COVID-19 on Gifted Students' Quality of Life (QOL-GSS): Scale Development and Application*
}

\author{
Şefika Şule ERÇETİN** Nihan POTAS ${ }^{* * *}$ \\ Şuay Nilhan AÇIKALIN ${ }^{* * * *}$ Nilüfer KOÇTÜRK ${ }^{* * * * *}$ \\ Sema $\mathrm{ABAL}^{* * * * * *}$
}

\begin{abstract}
The aim of this study is to develop a valid and reliable scale to measure the effects of COVID-19 on gifted students' quality of life (QOL-GSS) and to analyse its effects on some variables such as gender, age, education level, parents' education level, monthly income and number of children in the family. To this end, a scale was developed and its reliability and validity were measured through a number of measures. The internal consistency was used to evaluate the reliability of the scale whereas its validity was analyzed by a factor analysis. Regarding exploratory factor analysis, the result of the KMO test was .90 and Bartlett test $\chi 2$ statistic was $3055.306(\mathrm{p}<.001)$. Path coefficients of the items varied between .55 and .89 and Cronbach's Alpha $(\alpha=.76)$ coefficients indicated that the data obtained from the scale (QOL-GSS) was reliable. Results overall indicated that COVID-19 affected gifted students' quality of life slightly in all dimensions of QOL-GSS. In addition, the effect of COVID-19 on gifted students' quality of life showed significant differences by gender, education level, mother's education level, father's education level, monthly income and number of children in the family.
\end{abstract}

Keywords: COVID-19, gifted students, quality of life, reliability and validity

\footnotetext{
* The ethics committee approval for this study was obtained from the Ethics Committee of the Rectorate of Ankara Hacı Bayram University, dated 29/09/2020 and numbered 10.

** Orcid ID: https://orcid.org/0000-0002-7686-4863, Prof. Dr., Hacettepe University, Turkey, sefikasule@gmail.com

*** Orcid ID: https://orcid.org/0000-0002-0393-3135, Assist. Prof. Dr., Ankara Hacı Bayram Veli University, Turkey, nihan potas@hotmail.com

**** Orcid ID: https://orcid.org/0000-0002-5361-7667, Assist. Prof. Dr., Ankara Hacı Bayram Veli University, Turkey, suaynilhan@gmail.com

***** Orcid ID: https://orcid.org/0000-0001-6124-1842, Assoc. Prof. Dr., Hacettepe University, Turkey, niluferkocturk@hacettepe.edu.tr

****** Orcid ID: https://orcid.org/0000-0002-4400-1350, Instructor, Middle East Technical University, Turkey, semaabal@hotmail.com
} 


\section{INTRODUCTION}

Initially emerging in Wuhan -a province of China- in December 2019, COVID-19 outbreak turned into a pandemic affecting numerous countries after a short time (Erçetin et al., 2020; Remuzzi \& Remuzzi, 2020; Zu et al., 2020). The World Health Organization (WHO) announced it as a worrying and serious state of emergency for causing cases and deaths just until January, 2020 which was more than expected (Mahase, 2020). In the updated reports of WHO, the number of total cases are 33.502.430 and the number of deaths reached to 1.004 .412 (WHO, 2020), both of which seem to be increasing rapidly. In Turkey, the number of total cases is approximately 384.509 and the death toll is around 10.558 (Turkish Ministry of Health, 2020). These numbers show that COVID-19 has widespread consequences both in the world and in our country and may have effects on people's quality of life.

Quality of life means meeting the needs and social demands of individuals and providing the individuals to benefit the opportunities of the society in which they live (Türütgen \& Şimşek, 2001). In other words, quality of life refers to the social, physical and psychological satisfaction level of individuals (Cummins, 2005). It is also defined as general well-being which is an indicator of life condition of people (Kangal, 2012). For this reason, the term quality of life can often be used instead of the terms happiness or wellbeing, and includes positive feelings like contentment or satisfaction (Veenhoven, 2000). From these definitions, it can be put forward that quality of life includes subjective evaluations of one's own life, may change over time and has multidimensional features in various fields such as health, economics and social sciences (Addington-Hall \& Kalra, 2001; Statham \& Chase, 2010).

From a general perspective, highly talented people are labelled as gifted people (Sak, 2014) and gifted children refer to individuals who differ from their peers in terms of quality and might show advanced mental skills (Silverman, 2020). Gifted students are generally educated in gifted education programs and in Turkey, such students are encouraged to study at Science and Art Education Centres (BILSEM), which were founded in order to enable gifted preschool, elementary, secondary and high school students to help them use their talents at the highest level. These centres were established by the Ministry of Education (MEB, 2020a) considering the issues such as settlements, transportation facilities and regional population, upon the proposal of the governorships. Currently, there are 182 Science and Art Education Centres and 57360 students enrolled in these centres (Ministry of Education [MEB], 2020b).

In Turkey, as in all over the world, it is thought that the gifted students' quality of life may have been affected negatively as a result of COVID-19, like that of other individuals (National Association for Gifted Children, 2020). Accordingly, how they have been affected by this situation merits further research attention, which would investigate this through reliable and valid measures. However, to the best of the knowledge, there is not any scale in the literature that can evaluate the gifted students' quality of life. Thus, there 
is a need for a valid and reliable measurement tool that would reveal how and to what extent COVID-19 affects gifted students' quality of life.

When the literature is reviewed, it can be seen that there are numerous local and foreign studies that measure children' quality of life (e.g., Angeles, 2009; Arl, 2015; Aykaç, 2019; Aytekin, Arslan \& Küçükoğlu, 2015; Bekir, Şahin \& Aydın, 2013; Berman, Liu, Ullman, Jadbäck \& Engström, 2016; Çecen-Eroğul \& Dingiltepe, 2012; Demiriz \& Ulutaş, 2016; Dinisman \& Ben-Arieh, 2016; Goswami, 2012; Hakvoort, Bos, Balen \& Hermans, 2010; Migliorini, Tassara \& Rania, 2018; Özbey, Mercan \& Alisinanoğlu, 2018; Pollmann \& Schult, 2013; Tümer, 2018; Ünüvar, Çalışandemir, Tagay \& Amini, 2015). However, the scales used in these earlier studies were not developed to measure the quality of life during the COVID-19 process. Thus, a measurement tool which would evaluate gifted students' quality of life during the times of COVID-19 may contribute to the literature. Considering that gifted students' quality of life may change depending on some demographic variables such as gender of students and education level of parents; clarification of this situation may direct the interventions for gifted students by determining the risk groups during and after the COVID-19 pandemic.

In the general framework stated, the aim of this research is twofold: 1) to develop a valid and reliable measurement tool that can measure the effect of COVID-19 pandemic on gifted students' quality of life, and 2) to evaluate the effect of this pandemic on these students based on the newly developed scale regarding some variables. Aligned with these aims, the following questions were addressed in this study:

1. What is the effect of COVID-19 pandemic on gifted students' quality of life?

2. Does the effect of COVID-19 pandemic on gifted students' quality of life significantly differ by demographic variables (i.e., gender, education level, mother's education level, father's education level, monthly income and number of children in the family)?

\section{METHOD}

The present study was conducted with using descriptive survey model and crosssectional approach. Descriptive survey model refers to analysing an event or situation in its natural state (Erçetin \& Açıkalın, 2020; Karasar, 2009).

\section{Participants}

In this study, there were two groups of participants. The first group was employed to conduct the exploratory factor analysis (EFA) and confirmatory factor analysis (CFA) in the scale development process. The second group, on the other hand, was employed to conduct the main application of the study.

The first group consisted of 337 gifted students (170 female, 167 male) who were studying at Science and Art Education Centres in various cities in Turkey. The participants were selected by simple random sampling method, one of the probabilistic sampling methods. Simple random sampling method was used for all units given that the population has equal chances to be included in the sampling (Neuman, 2014; Potas and 
Akçil Ok, 2020). Of the students in the first group, 213 (63.2\%) were primary, 104 (30.9\%) were secondary, and 20 (5.9\%) were high school students. Regarding mother's education level, the number of participants whose mothers graduated from primary, secondary, and high school and those with an associate, graduate, and postgraduate degrees were 19 (5.6\%), 15 (4.5\%), 62 (18.4\%), 35 (10.4\%), 174 (51.6\%), and 32 (9.5\%) respectively. On the other hand, with respect to father's education level, the number of participants having fathers graduated from primary, secondary, and high school and those with an associate, graduate, and postgraduate degrees 13 (3.9\%), 17 (5\%), 65 (19.3\%), 38 (11.3\%), 160 (47.5\%), and $44(13.1 \%)$ respectively. Concerning their families' monthly income, 64 (19\%) participants lived in a family that had a monthly income between 0-3000 Turkish Liras (TL), whereas 119 (35.3\%) and 154 (45.7\%) of them lived in families that had an income between 3001-6000 TL and over 6001 TL, successively. In addition, 82 (24.3\%) students were the only child in the family, whereas $129(38.3 \%)$ lived in a family with two children and $126(37.4 \%)$ lived in a family with three children.

The second group included 734 gifted students (306 male, 428 female) who were studying at Science and Art Education Centres in various cities in Turkey and selected by a simple random sampling method. Of the students in the second group, 417 (56.8\%) were primary, 184 (25.1\%) secondary, and 133 (18.1\%) were high school students. Concerning the mother's education level, there were 55 (7.5\%) primary, 39 (5.3\%) secondary, 144 $(19.6 \%)$ high school graduates, whereas 87 (11.9\%) associate, $355(48.4 \%)$ graduate and $54(7.4 \%)$ postgraduate degrees. Among fathers there were $46(6.3 \%)$ primary, $52(7.1 \%)$ secondary, 140 (19.1\%) high school graduates, 96 (13.1\%) associate, 311 (42.4\%) graduate, $89(12.1 \%)$ postgraduate degrees. In addition, $119(16.2 \%)$ participants had a monthly income between 0-3000 Turkish Liras (TL), 280 (38.1\%) between 3001-6000 TL, and 335 (45.6\%) over 6001 TL. 244 (33.2\%) students were the only child in the family, $319(43.5 \%)$ were in a family with two children and $171(23.3 \%)$ were in a family with three children.

\section{Data Collection Process}

The ethics committee approval for this study was obtained from the Ethics Committee of the Rectorate of Ankara Hacı Bayram University, dated 29/09/2020 and numbered 10. Data were collected from 734 gifted students via online forms over a period of one month. Firstly, an informed consent form including the aim of the study was presented. The principle of volunteerism was clearly stated in the form, and informed consent permissions were obtained online from both students and parents. Then, the data collection process of the study was carried out online.

\section{Data Collection Tool}

In this study, Effect of COVID-19 on Gifted Students' Quality of Life Scale (QOL-GSS) developed by the researchers was used to collect data. With this scale, the effect of COVID19 pandemic on gifted children was analysed in terms of some demographic features 
(gender, education level, mother's education level, father's education level, monthly income and number of children in the family).

\section{Data Analysis}

In the phase of scale development, data were screened for normality. It is stated in the literature that at least 300 participants are required for the scale development studies (Norusis, 2005; Tabachnick \& Fidell, 2012). In this regard, that the number of participants in the first sampling group was over 300 can be considered acceptable for the development of this scale. For this, the data set from 351 respondents was converted into Z-standard scores. However, 14 of them were omitted from the data set because data coming from them was out of -3 and +3 ranges, and they were thus regarded as outliers. As a result, EFA and CFA were carried out with the final data set $(\mathrm{N}=337)$. Besides, given that the Kurtosis (-.818 and -.228) and Skewness (-.739 and -.228) were between -1 and +1 , the data showed a normal distribution (Huck, 2008). EFA and CFA were conducted to test the construct validity of QOL-GSS. Varimax rotation and Principal Component Analysis (PCA) were conducted in EFA and Maximum likelihood analysis was employed in CFA. Prior to EFA, the results of Kaiser-Meyer-Olkin (KMO) and Bartlett sphericity tests were run to identify whether the data of the study was suitable for the factor analysis. Some criteria such as eliminating items not measuring the same structures, common factor variance, item factor loadings, item eigenvalues, explained variance ratio, and representation of the theoretical background to be measured were calculated in the process of EFA (Tabachnick \& Fidell, 2012). CFA was also run to evaluate the model-data fit of the results obtained from EFA. Accepted fit indices in the literature (Kline, 2011) were used in CFA. Internal consistency reliability coefficients were interpreted according to Cronbach's Alpha and total item correlation.

In the second phase of the study, descriptive statistics analyses -percentage, frequency, mean, standard deviation- were employed in order to determine the differences in terms of demographic variables. Findings showed that the Kurtosis (-.922 and -.134) and Skewness (-.008 and -.633) were between -1 and +1 , so the data of the scale showed a normal distribution (Huck, 2008) and parametric tests were used. Accordingly, an independent sample $t$-test and one-way ANOVA were run. LSD test, which is a Post Hoc test, was conducted to define if there was a significant difference in multiple comparisons of parametric tests. Effect sizes were also calculated along with statistical significance in the study. The results were evaluated within $\alpha=.01$ and $\alpha=.05$ error level. Validity and reliability results regarding the EFA and CFA of the scale were obtained using SPSS 21.00 and AMOS 24.00 programs.

In the second phase of the study, descriptive statistics analyses -percentage, frequency, mean, standard deviation- were employed in order to determine the differences in terms of demographic variables. Findings showed that the Kurtosis (-.922 and -.134) and Skewness ( -.008 and -.633) were between -1 and +1 , so the data of the scale showed a normal distribution (Huck, 2008) and parametric tests were used. Accordingly, an independent sample $t$-test and one-way ANOVA were run LSD test, which is a Post Hoc 
test, was conducted to define if there was a significant difference in multiple comparisons of parametric tests. Effect sizes were also calculated along with statistical significance in the study. The results were evaluated within $\alpha=.01$ and $\alpha=.05$ error level. Validity and reliability results regarding the EFA and CFA of the scale were obtained using SPSS 21.00 and AMOS 24.00 programs.

\section{FINDINGS}

Findings were presented in two stages. The findings related to the validity and reliability of Effect of COVID-19 on Gifted Students' Quality of Life Scale (QOL-GSS) were presented in the first stage and the results of the analysis related to the effect of COVID-19 pandemic on gifted children in terms of some demographic variables (gender, education level, mother's education level, father's education level, monthly income and number of children in the family) were presented in the second stage.

\section{Findings of the First Stage of the Study}

According to the EFA of the scale, KMO was .90 and Bartlett test $\chi^{2}$ statistic was 3055.306 $(p<.001)$. That the KMO statistic was greater than .60 and Bartlett test was meaningful showed that data were suitable for factor analysis (Tabachnick and Fidell, 2012). EFA results showed that common variance of the items was between .48 and .75; factor eigenvalues were between 2.045 and 5.305; item factor loadings were between .62 and .88; and total variance explained was $65.734 \%$. Variance ratio explained by each factor of the scale was $33.158 \%, 19.796 \%$ and $12.78 \%$ in the first, second, and third factors respectively. On the other hand, two overlapping items, an item that did not work and another item whose factor loading was lower than .40 (four items in total) were removed from the scale in accordance with experts' opinion. Finally, a scale with 3 independent factors and a total of 16 items was created (see Table 1).

As presented in Table 1, each of 3 factors emerged in EFA were named as dimensions considering the content of the constituent items. In this regard, there were 5 items in the dimension of Psychological Effect (items 1, 2, 3, 4 and 5); 8 items in the dimension of Familial Effect (items 6, 7, 8, 9, 10, 11, 12, and 13); and 3 items in the dimension of Innovativeness and Creativity Effect (items 14, 15 and 16). The items in the scale were ranked on a 4-point Likert scale: (1) Influenced very little, (2) Influenced little, (3) Influenced and (4) Influenced a lot. 
Table 1

Exploratory factor analysis (EFA) of the scale

\begin{tabular}{|c|c|c|c|c|c|}
\hline Factor & Item & Communalities & Item factor loading & Eigenvalues & $\begin{array}{c}\text { Factor } \\
\text { variance } \\
\text { explained (\%) }\end{array}$ \\
\hline \multirow{5}{*}{$\begin{array}{l}\text { Factor } \\
1\end{array}$} & Y1 & .63 & .77 & \multirow{5}{*}{5.305} & \multirow{5}{*}{33.158} \\
\hline & Y2 & .48 & .62 & & \\
\hline & Y3 & .75 & .84 & & \\
\hline & Y4 & .61 & .78 & & \\
\hline & Y5 & .74 & .85 & & \\
\hline \multirow{8}{*}{$\begin{array}{l}\text { Factor } \\
2\end{array}$} & Y6 & .49 & .70 & \multirow{8}{*}{3.167} & \multirow{8}{*}{19.796} \\
\hline & Y7 & .70 & .85 & & \\
\hline & Y8 & .75 & .84 & & \\
\hline & Y9 & .66 & .76 & & \\
\hline & Y10 & .78 & .84 & & \\
\hline & Y11 & .80 & .88 & & \\
\hline & Y12 & .64 & .75 & & \\
\hline & Y13 & .63 & .74 & & \\
\hline \multirow{3}{*}{$\begin{array}{l}\text { Factor } \\
3\end{array}$} & Y14 & .51 & .64 & \multirow{3}{*}{2.045} & \multirow{3}{*}{12.780} \\
\hline & Y15 & .67 & .76 & & \\
\hline & Y16 & .69 & .79 & & \\
\hline \multicolumn{5}{|c|}{ Total Variance Explained (\%) } & 65.734 \\
\hline
\end{tabular}

Means obtained for each item and participants' level of agreement with each item in the scale were as follows: Influenced very little (1.00-1.75), Influenced little (1.76-2.51), Influenced (2.52-3.27), and Influenced a lot (3.28.-4.00). A high score obtained from the scale shows that pandemic affected the gifted students' quality of life negatively whereas a low score means it did not have such an effect. These points can also be interpreted as follow: very little negative influence (1.00-1.75), little negative influence (1.76-2.51), high negative influence (2.52-3.27) and very high negative influence (3.28-4.00). 


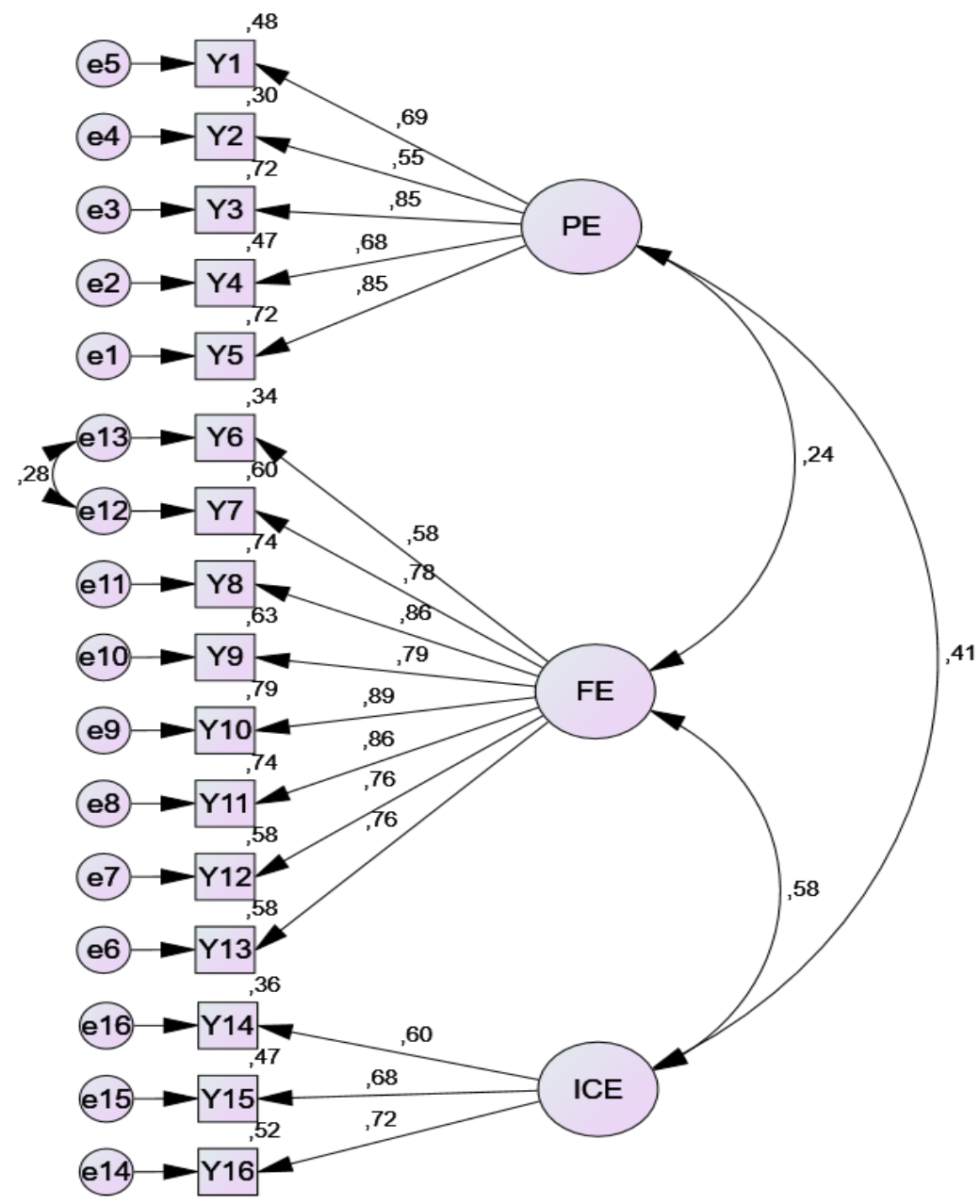

Figure 1. 3-factor Path Diagram of the Scale (PE: Psychological effect, FE: Familial Effect, ICE: Innovativeness and Creativity Effect)

In order to determine whether the factor structure obtained from EFA could be confirmed or not, CFA was conducted by using AMOS 24.00. Regarding CFA results, correlation levels between errors of some items in the scale were considered and Y6-Y7 needed to be modified based on the experts' opinions. Following the modification process, goodness of fit belonging the 3-dimensional factorial structure (SRMR $=.049$, RMR $=.050$, CFI $=.95$, $\mathrm{PGFI}=.67, \mathrm{TLI}=.94, \mathrm{IFI}=.95, \mathrm{RFI}=.90, \mathrm{NFI}=.92, \mathrm{AGFI}=.88, \mathrm{GFI}=.91, \mathrm{RMSEA}=.066, \chi^{2} /$ $\mathrm{Sd}=247.925 / 100=2.479$ ) and the path diagram (see Figure 1 ) indicated that the model fit well with the data. The path diagram in Figure 1 shows the effect sizes and correlation coefficients of each item on the latent dependent variable. Path coefficients of the items vary between .55 and .89 . 
After the validity measures, reliability of the scale was determined by considering the values of Cronbach's Alpha. Cronbach's Alpha was .85, .93, .070 and .89 for the first, second, third dimensions and QOL-GSS successively. When all validity and reliability results were considered, it was concluded that QOL-GSS was an appropriate measurement tool that can be used psychometrically.

Following the validity and reliability evaluations of the scale, CFA was conducted for the main application of the study. CFA results showed that goodness of fit of the 3dimensional factor structure, applied on 734 students, were $(\mathrm{NFI}=.92$, TLI $=.91$, RFI $=$ $.90, \mathrm{CFI}=.94, \mathrm{IFI}=.94, \mathrm{AGFI}=.90, \mathrm{GFI}=.93, \mathrm{RMR}=.069, \mathrm{SRMR}=.0674, \mathrm{RMSEA}=.071$, $\chi^{2}=433.633, \mathrm{Sd}=93, \chi^{2} / \mathrm{Sd}=433.633 / 93=4.663$ ), which demonstrated that the model fit well with the data. Moreover, for the main application of this research Cronbach's Alpha $(\alpha)$ was .79, .88, .77 and .76 in the first, second, third dimensions and QOL-GSS respectively. Cronbach's Alpha $(\alpha)$ coefficients indicated that the data obtained from the scale was reliable.

\section{Findings of the Descriptive Statistics in the Second Stage of the Study}

Descriptive statistics and analysis results obtained from difference tests are presented in this section . The findings of the descriptive analysis carried out in order to determine the level of effect of COVID-19 pandemic on gifted students' quality of life are presented in Table 2.

Table 2

Findings of descriptive statistics of the study ( $n=734)$

\begin{tabular}{|c|c|c|c|c|c|}
\hline Variables & Min. & Max. & $\bar{x}$ & $\mathrm{Sd}$ & Level \\
\hline Psychological effect (PE) & 1.00 & 4.00 & 1.93 & .72 & Influenced little \\
\hline Familial Effect (FE) & 1.00 & 3.88 & 1.87 & .75 & Influenced little \\
\hline $\begin{array}{l}\text { Innovativeness } \\
\text { Creativity Effect (ICE) }\end{array}$ & 1.00 & 4.00 & 2.48 & .88 & Influenced little \\
\hline QOL-GSS & 1.00 & 3.19 & 2.01 & .40 & Influenced little \\
\hline
\end{tabular}

(QOL-GSS: Effect of COVID-19 on Gifted Students' Quality of Life Scale)

According to Table 2, COVID-19 pandemic had a little influence on gifted students' quality of life in all dimensions and QOL-GSS. It was also found out that effect of COVID-19 pandemic on gifted students was maximum in innovativeness and creativity dimension $(\bar{x}=2.48, \mathrm{Sd}=.88)$ and minimum in familial effect dimension $(\bar{x}=1.87, \mathrm{Sd}=.75)$. The effect on psychological effect dimension was $\bar{x}=1.93(\mathrm{Sd}=.72)$. In other words, the effect of pandemic on gifted students ordered from maximum to minimum was as follows: 
innovativeness and creativity effect, psychological effect and familial effect. As presented in Table 2, when standard deviations were analysed in terms of dimensions, the most homogenous distribution was in the psychological effect dimension $(\mathrm{Sd}=.72)$, and the most heterogeneous distribution was in innovativeness and creativity effect $(\mathrm{Sd}=.88)$.

\section{Findings regarding effect of COVID-19 pandemic on life quality of gifted students according to gender and education level}

Table 3 presents the findings of the independent $t$ test and one-way ANOVA regarding the effects of COVID-19 pandemic on gifted students' quality of life according to gender and education level.

As shown in Table 3, while the effect of COVID-19 pandemic on gifted students' quality of life by gender was statistically significant in psychological effect dimension $\left(t t_{(732)}=-\right.$ $4.418 ; p<.05)$, innovativeness and creativity dimension $\left(t_{(732)}=-3.041 ; p<.05\right)$ and in QOL-GSS $\left(t_{(732)}=7.157 ; p<.05\right)$; no significant difference was found out in familial effect dimension $\left(t_{(732)}=-.573 ; p>.05\right)$. Morevoer, in the significant differences by gender in psychological effect, innovativeness and creativity dimensions and QOL-GSS, findings showed that female students had higher means compared to male students. Besides, Cohen's d effect size was .33 in psychological effect dimension, .22 in innovativeness and creativity dimension and .32 in QOL-GSS. That the effect sizes were between .20 and .50 indicated there was a small effect. Table 3 also demonstrates that although the effect of COVID-19 pandemic on gifted students' quality of life according to education level showed significant difference in familial effect dimension $\left(\mathrm{F}_{(2,733)}=15.489 ; p<.05\right)$, in innovativeness and creativity dimension $\left(\mathrm{F}_{(2,733)}=19.084 ; p<.05\right)$ and in QOL-GSS $\left(\mathrm{F}_{(2,733)}\right.$ $=7.157 ; p<.05)$, it showed no significant difference in psychological effect dimension ( $\mathrm{F}$ $(2,733)=2.793 ; p>.05)$. The significant differences in familial effect dimension were between the gifted students whose education level was secondary and primary; whose level of education was secondary and high school; and whose education level was high school and primary school. The significant differences in innovativeness and creativity dimension were between the gifted students whose education level was primary and secondary as well as whose education level was primary and high school. The significant differences in QOL-GSS were between the gifted students whose education level was secondary and primary as well as between those whose education level was secondary and high school. 
Table 3

Findings of the study according to gender and education level

\begin{tabular}{|c|c|c|c|c|c|c|c|}
\hline Variables & Level & $\mathrm{n}$ & $\bar{x}$ & SD & $\begin{array}{l}\text { Test } \\
\text { Statistics }\end{array}$ & $p$ & Difference \\
\hline \multirow{5}{*}{$\begin{array}{l}\text { Psychological } \\
\text { Effect }\end{array}$} & Male & 306 & 1.79 & .64 & $-4.418^{a}$ & $.00^{*}$ & \\
\hline & Female & 428 & 2.02 & .75 & & & \\
\hline & Primary (A) & 417 & 1.93 & .72 & $2.793^{\mathrm{b}}$ & .06 & \\
\hline & $\begin{array}{l}\text { Secondary } \\
\text { (B) }\end{array}$ & 184 & 2.01 & .73 & & & \\
\hline & $\begin{array}{l}\text { High School } \\
\text { (C) }\end{array}$ & 133 & 1.82 & .67 & & & \\
\hline \multirow{5}{*}{ Familial Effect } & Male & 306 & 1.85 & .70 & $-.573^{\mathrm{a}}$ & .57 & \\
\hline & Female & 428 & 1.88 & .77 & & & \\
\hline & Primary (A) & 417 & 1.75 & .71 & $15.489^{b}$ & $.00^{*}$ & $\mathrm{~B}>\mathrm{A}$ \\
\hline & $\begin{array}{l}\text { Secondary } \\
\text { (B) }\end{array}$ & 184 & 2.11 & .72 & & & $\mathrm{~B}>\mathrm{C}$ \\
\hline & $\begin{array}{l}\text { High School } \\
\text { (C) }\end{array}$ & 133 & 1.94 & .76 & & & $\mathrm{C}>\mathrm{A}$ \\
\hline \multirow{5}{*}{$\begin{array}{l}\text { Innovativeness } \\
\text { and Creativity } \\
\text { Effect }\end{array}$} & Male & 306 & 2.36 & .84 & $-3.041^{\mathrm{a}}$ & $.00^{*}$ & \\
\hline & Female & 428 & 2.56 & .89 & & & \\
\hline & Primary $(\mathrm{A})$ & 417 & 2.65 & .90 & $19.084^{b}$ & $.00^{*}$ & $A>B$ \\
\hline & $\begin{array}{l}\text { Secondary } \\
\text { (B) }\end{array}$ & 184 & 2.24 & .78 & & & $A>C$ \\
\hline & $\begin{array}{l}\text { High School } \\
\text { (C) }\end{array}$ & 133 & 2.29 & .82 & & & \\
\hline \multirow{5}{*}{ QOL-GSS } & Male & 306 & 1.93 & .36 & $-4.307^{a}$ & $.00^{*}$ & \\
\hline & Female & 428 & 2.05 & .40 & & & \\
\hline & Primary (A) & 417 & 1.98 & .36 & $7.157 \mathrm{~b}$ & $.00^{*}$ & $\mathrm{~B}>\mathrm{A}$ \\
\hline & $\begin{array}{l}\text { Secondary } \\
\text { (B) }\end{array}$ & 184 & 2.10 & .42 & & & $\mathrm{~B}>\mathrm{C}$ \\
\hline & $\begin{array}{l}\text { High School } \\
\text { (C) }\end{array}$ & 133 & 1.96 & .43 & & & \\
\hline
\end{tabular}


${ }^{*} p<.05$, a: Independent $t$ test, b: One-Way ANOVA F, (QOL-GSS: Effect of COVID-19 on Gifted Students' Quality of Life Scale)

Findings regarding effect of COVID-19 pandemic on life quality of gifted students according to mother's and father's education level

In Table 4, the findings of one-way ANOVA related to the effect of COVID-19 pandemic on gifted students' quality of life according to mother's and father's education level is presented.

Table 4

Findings of the study according to mother's and father's education level

\begin{tabular}{|c|c|c|c|c|c|c|c|c|}
\hline Variables & & $\begin{array}{l}\text { Graduation } \\
\text { Level }\end{array}$ & $\mathrm{n}$ & $\bar{x}$ & $\mathrm{Sd}$ & $F$ & $p$ & Difference \\
\hline \multirow{12}{*}{$\begin{array}{l}\text { Psychological } \\
\text { Effect }\end{array}$} & \multirow{6}{*}{$\begin{array}{l}\text { education } \\
\text { level }\end{array}$} & Primary (A) & 55 & .68 & 2.07 & \multirow[t]{6}{*}{3.907} & \multirow[t]{6}{*}{$.01^{*}$} & $A>D$ \\
\hline & & Secondary (B) & 39 & .61 & 1.95 & & & \multirow[t]{5}{*}{$A>E$} \\
\hline & & High school (C) & 144 & .79 & 2.05 & & & \\
\hline & & $\begin{array}{l}\text { Associate d. } \\
\text { (D) }\end{array}$ & 87 & .55 & 1.68 & & & \\
\hline & & Graduate d. (E) & 355 & .71 & 1.87 & & & \\
\hline & & $\begin{array}{l}\text { Postgraduate d } \\
\text { (F) }\end{array}$ & 54 & .80 & 1.98 & & & \\
\hline & \multirow{6}{*}{$\begin{array}{l}\text { Father's } \\
\text { education } \\
\text { level }\end{array}$} & Primary (A) & 46 & .73 & 2.10 & \multirow[t]{6}{*}{2.832} & \multirow[t]{6}{*}{$.02^{*}$} & $1>3$ \\
\hline & & Secondary (B) & 52 & .71 & 2.04 & & & $1>5$ \\
\hline & & High school (C) & 140 & .80 & 1.76 & & & \\
\hline & & Associate d (D) & 96 & .69 & 1.90 & & & \\
\hline & & Graduate d (E) & 311 & .66 & 1.86 & & & \\
\hline & & $\begin{array}{l}\text { Postgraduate d } \\
\text { (F) }\end{array}$ & 89 & .73 & 1.92 & & & \\
\hline \multirow{6}{*}{ Familial Effect } & \multirow{6}{*}{$\begin{array}{l}\text { education } \\
\text { level }\end{array}$} & Primary (A) & 55 & .66 & 2.09 & \multirow[t]{6}{*}{12.365} & \multirow[t]{6}{*}{$.00^{*}$} & $A>D$ \\
\hline & & Secondary (B) & 39 & .74 & 1.78 & & & $A>E$ \\
\hline & & High school (C) & 144 & .66 & 1.67 & & & $A>F$ \\
\hline & & Associate d (D) & 87 & .51 & 1.56 & & & \\
\hline & & Graduate d(E) & 355 & .78 & 1.75 & & & \\
\hline & & $\begin{array}{l}\text { Postgraduate d } \\
\text { (F) }\end{array}$ & 54 & .77 & 1.63 & & & \\
\hline
\end{tabular}




\begin{tabular}{|c|c|c|c|c|c|c|c|c|}
\hline & \multirow{6}{*}{$\begin{array}{l}\text { Father's } \\
\text { education } \\
\text { level }\end{array}$} & Primary (A) & 46 & .82 & 2.03 & 3.264 & $.01^{*}$ & $1>2$ \\
\hline & & Secondary (B) & 52 & .55 & 1.75 & & & $1>3$ \\
\hline & & High school (C) & 140 & .71 & 1.70 & & & $1>5$ \\
\hline & & Associate d (D) & 96 & .73 & 2.01 & & & \\
\hline & & Graduate d(E) & 311 & .76 & 1.88 & & & \\
\hline & & $\begin{array}{l}\text { Postgraduate } d \\
\text { (F) }\end{array}$ & 89 & .77 & 1.96 & & & \\
\hline \multirow{12}{*}{$\begin{array}{l}\text { Innovativeness } \\
\text { and Creativity } \\
\text { Effect }\end{array}$} & \multirow{6}{*}{$\begin{array}{l}\text { Mother's } \\
\text { education } \\
\text { level }\end{array}$} & Primary (A) & 55 & .79 & 2.77 & 3.706 & $.00^{*}$ & $A>B$ \\
\hline & & Secondary (B) & 39 & .53 & 2.35 & & & $\mathrm{~A}>\mathrm{C}$ \\
\hline & & High school (C) & 144 & 1.00 & 2.33 & & & \\
\hline & & Associate d (D) & 87 & .86 & 2.41 & & & \\
\hline & & Graduate d(E) & 355 & .83 & 2.49 & & & \\
\hline & & $\begin{array}{l}\text { Postgraduate d } \\
\text { (F) }\end{array}$ & 54 & .97 & 2.52 & & & \\
\hline & \multirow{6}{*}{$\begin{array}{l}\text { Father's } \\
\text { education } \\
\text { level }\end{array}$} & Primary $(\mathrm{A})$ & 46 & .94 & 2.43 & .803 & .55 & \\
\hline & & Secondary (B) & 52 & .79 & 2.55 & & & \\
\hline & & High school (C) & 140 & .80 & 2.46 & & & \\
\hline & & Associate d (D) & 96 & .85 & 2.34 & & & \\
\hline & & Graduate d (E) & 311 & .87 & 2.53 & & & \\
\hline & & $\begin{array}{l}\text { Postgraduate d } \\
\text { (F) }\end{array}$ & 89 & 1.00 & 2.46 & & & \\
\hline \multirow{10}{*}{ QOL-GSS } & \multirow{6}{*}{$\begin{array}{l}\text { Mother's } \\
\text { education } \\
\text { level }\end{array}$} & Primary (A) & 55 & .35 & 2.02 & 9.028 & $.00^{*}$ & $A>B$ \\
\hline & & Secondary (B) & 39 & .42 & 1.84 & & & $A>E$ \\
\hline & & High school (C) & 144 & .41 & 1.41 & & & \\
\hline & & Associate d (D) & 87 & .24 & 1.88 & & & \\
\hline & & Graduate d (E) & 355 & .40 & 1.09 & & & \\
\hline & & $\begin{array}{l}\text { Postgraduate d } \\
\text { (F) }\end{array}$ & 54 & .33 & 1.98 & & & \\
\hline & \multirow{2}{*}{ Father's } & Primary (A) & 46 & .39 & 2.04 & .581 & .71 & \\
\hline & & Secondary (B) & 52 & .35 & 1.97 & & & \\
\hline & \multirow{2}{*}{$\begin{array}{l}\text { education } \\
\text { level }\end{array}$} & High school (C) & 140 & .45 & 1.97 & & & \\
\hline & & Associate d (D) & 96 & .38 & 2.03 & & & \\
\hline
\end{tabular}


$\begin{array}{llll}\text { Graduate d (E) } \quad 311 & .37 & 2.00\end{array}$

Postgraduate $\mathrm{d}$

(F)

$89 \quad .40 \quad 2.05$

${ }_{\mathrm{p}}<.05$, (QOL-GSS: Effect of COVID-19 on Gifted Students' Quality of Life Scale)

As demonstrated in Table 4, the effect of COVID-19 pandemic on gifted students' quality of life by mother's education level showed significant difference in psychological effect dimension $\left(F_{(5,733)}=3.907 ; p<.05\right)$, in familial effect dimension $\left(F_{(5,733)}=12.365 ; p<.05\right)$, in innovativeness and creativity effect dimension $\left(F_{(5,733)}=3.706 ; p<.05\right)$ and in QOL-GSS $\left(F_{(5,733)}=9.028 ; p<.05\right)$. Significant differences in psychological effect dimension were; between the students whose mother was a graduate of primary school and held a graduate of associate degree; and between the students whose mother was a graduate of primary school and held a graduate of licence degree. Significant differences in familial effect dimension were; between the students whose mother was a graduate of primary school and held a graduate of associate degree; between the students whose mother was a graduate of primary school and held a graduate degree; and between students whose mother was a graduate of primary school and held a postgraduate degree. And finally, significant differences in innovativeness and creativity effect dimension were found between the students whose mother was a graduate of primary school and secondary school as well as between those whose mother was a graduate of primary school and high school.

As illustrated in Table 4, though the effect of COVID-19 pandemic on life quality of gifted students by father's education level showed significant difference in psychological effect dimension $\left(\mathrm{F}_{(5,733)}=2.832 ; p<.05\right)$, and familial effect dimension $\left(\mathrm{F}_{(5,733)}=3.264 ; \mathrm{p}<.05\right)$; there was no significant difference in innovativeness and creativity effect dimension $\left(\mathrm{F}_{(5,733)}=.803 ; p>.05\right)$ and in QOL-GSS $\left(\mathrm{F}_{(5,733)}=.581 ; p>.05\right)$. Significant differences in psychological effect dimension were found between the students whose father was a graduate of primary school and high school; between the students whose father was a graduate of primary school and held a graduate degree. Significant differences in familial effect dimension were found between the students whose father was a graduate of primary school and secondary school; between those whose father was a graduate of primary school and high school; and between those whose father was a graduate of primary school and held a graduate degree.

\section{Findings regarding effect of COVID-19 pandemic on life quality of gifted students according to monthly income and number of children in the family}

The findings of one-way ANOVA related to the effect of COVID-19 pandemic on life quality of gifted students according to monthly income and number of children in the family are presented in Table 5 . 
Table 5

Findings of the study according to monthly income and number of children in the family

\begin{tabular}{|c|c|c|c|c|c|c|c|}
\hline Variables & Level & $\mathrm{n}$ & $\bar{x}$ & $\mathrm{Sd}$ & $F$ & $p$ & Difference \\
\hline \multirow{6}{*}{$\begin{array}{l}\text { Psychological } \\
\text { Effect }\end{array}$} & $0-3000$ TL (A) & 119 & 2.01 & .73 & \multirow[t]{3}{*}{3.866} & \multirow[t]{3}{*}{$.02^{*}$} & \multirow[t]{3}{*}{$A>B$} \\
\hline & 3001-6000 TL (B) & 280 & 1.79 & .75 & & & \\
\hline & $6001 \mathrm{TL}$ and over (C) & 335 & 1.92 & .68 & & & \\
\hline & 1-2 children (1) & 277 & 2.03 & .75 & \multirow[t]{3}{*}{5.493} & \multirow[t]{3}{*}{$.00^{*}$} & \multirow[t]{3}{*}{$1>2$} \\
\hline & 3-4 children (2) & 379 & 1.84 & .69 & & & \\
\hline & 5 and more children (3) & 78 & 1.97 & .70 & & & \\
\hline \multirow{6}{*}{ Familial Effect } & 0-3000 TL (A) & 119 & 1.97 & .72 & \multirow[t]{3}{*}{5.628} & \multirow[t]{3}{*}{$.00^{*}$} & $A>C$ \\
\hline & 3001-6000 TL (B) & 280 & 1.82 & .69 & & & \multirow[t]{2}{*}{$\mathrm{B}>\mathrm{C}$} \\
\hline & 6001 TL and over (C) & 335 & 1.74 & .78 & & & \\
\hline & 1-2 children (1) & 277 & 1.84 & .74 & \multirow[t]{3}{*}{4.105} & \multirow[t]{3}{*}{$.02^{*}$} & \multirow[t]{3}{*}{$2>3$} \\
\hline & 3-4 children (2) & 379 & 1.93 & .76 & & & \\
\hline & 5 and more children (3) & 78 & 1.68 & .65 & & & \\
\hline \multirow{6}{*}{$\begin{array}{l}\text { Innovativeness } \\
\text { and Creativity } \\
\text { Effect }\end{array}$} & 0-3000 TL (A) & 119 & 2.46 & .82 & \multirow[t]{3}{*}{0.063} & \multirow[t]{3}{*}{.93} & \\
\hline & 3001-6000 TL (B) & 280 & 2.50 & .84 & & & \\
\hline & $6001 \mathrm{TL}$ and over (C) & 335 & 2.48 & .93 & & & \\
\hline & 1-2 children (1) & 277 & 2.48 & .86 & \multirow[t]{3}{*}{0.345} & \multirow[t]{3}{*}{.71} & \\
\hline & 3-4 children (2) & 379 & 2.49 & .90 & & & \\
\hline & 5 and more children (3) & 78 & 2.40 & .81 & & & \\
\hline \multirow{6}{*}{ QOL-GSS } & 0-3000 TL (A) & 119 & 2.05 & .43 & \multirow[t]{3}{*}{7.233} & \multirow[t]{3}{*}{$.00^{*}$} & $A>C$ \\
\hline & 3001-6000 TL (B) & 280 & 2.02 & .37 & & & $\mathrm{~B}>\mathrm{C}$ \\
\hline & 6001 TL and over (C) & 335 & 1.89 & .40 & & & \\
\hline & 1-2 children (1) & 277 & 2.02 & .40 & \multirow[t]{3}{*}{2.654} & \multirow[t]{3}{*}{.07} & \\
\hline & 3-4 children (2) & 379 & 2.01 & .39 & & & \\
\hline & 5 and more children ( 3 ) & 78 & 1.90 & .37 & & & \\
\hline
\end{tabular}

*p<.05, (QOL-GSS: Effect of COVID-19 on Gifted Students' Quality of Life Scale)

In Table 5, it is seen that the effect of COVID-19 pandemic on life quality of gifted students by monthly income of the family showed statistically significant differences in psychological effect dimension $\left(F_{(2,733)}=3.866 ; p<.05\right)$, in familial effect dimension $\left(F_{(2,733)}\right.$ 
$=5.628 ; p<.05)$ and in QOL-GSS $\left(F_{(2,733)}=7.233 ; p<.05\right)$. A significant difference was found in psychological effect dimension, between the students whose monthly income was 0-3000 TL and the ones whose income was 3001-6000 TL. Significant differences in familial effect dimension were between the students whose monthly income was 0-3000 TL and the ones whose income was $6001 \mathrm{TL}$ and over; and between the students whose monthly income was 3001-6000 TL and the ones whose income was 6001 TL and over. Also, the significant differences in QOL-GSS were between the students whose monthly income was 0-3000 TL and the ones whose income was $6001 \mathrm{TL}$ and over; and between the students whose monthly income was 3001-6000 TL and the ones whose income was $6001 \mathrm{TL}$ and over.

As illustrated in Table 5, the effect of COVID-19 pandemic on life quality of gifted students by number of children in the family showed significant differences in psychological effect dimension $\left(F_{(2,733)}=5.493 ; p<.05\right)$ and familial effect dimension $\left(F_{(2,733)}=4.105 ; p<.05\right)$. The significant difference in psychological effect dimension was found between students who lived in families with 1-2 children and 3-4 children; and in familial effect dimension it was between students who lived in families with 3-4 children and 5-over children.

\section{DISCUSSIONS AND CONCLUSION}

This study was conducted to develop a reliable and valid scale measuring the effect of COVID-19 on gifted students' quality of life and analyse this effect considering some variables (i.e., gender, age, education level, mother's education level, father's education level, monthly income and number of children in the family) depending on the QOL-GSS.

Within the scope of the study, a scale with 3 independent factors and 16 items in total was created. The scale focused on how the pandemic affected them in psychological, familial, and innovativeness and creativity aspects. Reliability of the scale was determined by Cronbach's Alpha internal consistency coefficients. These alphas were .85, .93, .70 and .89 in the first, second, third dimensions and QOL-GSS, respectively. After the validity and reliability analyses were completed, QOL-GSS was determined to be a highly appropriate measurement tool to be used in research areas.

According to the results, it can be inferred that COVID-19 prevented innovativeness and creativity skills from improving, and caused some negative psychological outcomes. On the other hand, it did not have negative effects in the familial effect dimension. That families spent more time with their children and making their children feel that they are together in this process of pandemic may have created such an effect. The study conducted by Erçetin et al. (2020) on adults found out that the COVID-19 pandemic had the least effect in familial dimension. Therefore, it can be concluded that this pandemic can have similar familial effects on different groups of participants.

In this study, the effects of pandemic on gifted students by gender showed significant differences in psychological effect dimension, innovativeness and creativity dimension, 
and QOL-GSS. According to the results, it is worth discussing that the pandemic had different effects on girls and boys; female students felt these effects more compared to male students. Though there are limited sources in the literature regarding this finding, in the research with a community sample by Erçetin et al. (2020), it was found that the effect of this pandemic on the participants' quality of life differed by gender. This is thought to be caused by gender roles. As it is known, different roles are assigned to boys and girls in their socialization process (Koçtürk, 2020; Yağan-Güder \& Güler-Yildiz), and girls are expected to help mothers with household chores from an early age in Turkey. Thus, girls may have been affected more because of the domestic responsibilities especially during the quarantine in the pandemic period. As a matter of fact, the WHO (2020) also states that girls around the world may be affected more by the pandemic and that gender inequality may increase. However, considering the method of this study, qualitative and causal studies are needed in order to reach an assertive opinion.

Another essential result of this research is the effect of pandemic on gifted students by education level showed significant differences in familial effect dimension, innovativeness and creativity dimension, and QOL-GSS. The difference was more with students at secondary school rather than primary school and high school. This can be explained by the fact that middle school students go through a period from childhood to adolescence which is a sensitive period. It can be stated that negative outcomes of the pandemic are more obvious on gifted secondary school students who are just stepping into adolescence. Yet, as mentioned before, when limited findings regarding this period and the method of this study are considered, qualitative and causal studies are needed.

Another important finding of this study was while the effect of COVID-19 pandemic on gifted students by mother's education level showed significant differences in all dimensions of the QOL-GSS, by father's education level it only showed difference in psychological and familial effect dimensions. In other words, that the effect of pandemic differed by mother's education level but partially differed by father's education level. That the effect of pandemic was more obvious on the students whose mother or father was a primary school graduate can be considered as an expected situation. That is to say, parents who were graduates of primary school may not have been able to provide sufficient guidance to their children during the pandemic process due to their educational qualifications. When the studies, which were published before this pandemic, are reviewed, it can be understood that both mothers' dealing with the education of children and education level of the mother are known to be important variables in children's quality of life (Crede, Wirthwein, McElvany and Steinmayr, 2015; Yllmaz, 2015).

Another notable finding is that while the effect of this pandemic on gifted students by monthly income of the family showed significant differences in psychological effect and familial effect dimensions of the QOL-GSS, by number of children in the family it showed significant differences only in psychological effect and familial effect dimensions. Depending on these differences, it can be stated that the effect of pandemic was more intense with the students whose monthly income was low and who had a smaller number 
of kids in the family. While the quality of life was affected depending on the family's economic status (Chen et al., 2016; Prime, Wade and Browne, 2020), the significant difference in psychological effect dimension of the scale by number of children in the family was not an expected result. This situation may be because interpersonal relationships of gifted students having no or one sibling might have been affected more by the pandemic. It means that while students having more siblings could get through this process more easily with activities like indoor games, as a disadvantage they might have economic problems in a familial dimension. In fact, when findings concerning the monthly income were examined, it was found that students in low-income families were more affected by the pandemic in familial dimension than the students in higher-income families. Accordingly, it can be stated that the effects of COVID-19 on students change depending on the socio-economic structure of families. Considering that the pandemic may affect low-income families who work in day-paid jobs and do not have a fixed income more and increase their stress levels, it can be asserted that more opportunities offered by parents during the pandemic process prevent the effects of the pandemic on gifted students. To get exact opinions, causal studies can be carried out with parents and children in the future.

In conclusion, in line with the results of this research, several findings obtained regarding gifted students' quality of life during the pandemic process and the following suggestions can be made to practitioners and researchers:

1. Competitions and projects that can improve innovativeness and creativity traits of gifted students may be organized during COVID-19 pandemic.

2. In order to prevent negative effects of pandemic, guidance and counseling services can be provided targeting especially female students and secondary school students.

3. In cases the guidance and counseling services cannot be performed face-to-face, telephone or online methods can be used. Moreover, consultation service can be provided to organize in-home learning environments and make necessary adaptations targeting parents of children in groups determined to be more affected by the pandemic, and social support mechanisms for children under risk can be strengthened.

4. To raise parents' awareness about the pandemic process, studies can be conducted through national channels.

5. Preventive school-based action plans and psycho-education studies can be arranged for children of families with low socio-economic status or with many children.

6. New studies with large samples and longitudinal studies can be carried out using qualitative and mixed research methods.

7. The validity and reliability studies of the scale can be repeated by conducting new studies on children who have different individual and familial characteristics.

Despite these important contributions of the present study, there are also several limitations which should be addressed. First of all, given the limited data available and the 
time sensitivity of the pandemic outbreak, it is limited to the chosen sampling method and techniques as online data collection. Secondly, the present study was conducted with using self-report data and cross-sectional approach. These are considered important limitations for generalizability of the study results.

\section{References}

Addington-Hall, J., \& Kalra, L. (2001). Who should measure quality of life? British Medical Journal, 322(7299), 1417.

Angeles, L. (2010). Children and Life Satisfaction. Journal of Happiness Studies, 11(4), 523-538.

Arı, S. İ. (2015). Önergenlerin özsaygılarının çocuk-anababa ilişkileri açısından incelenmesi [Examining the self-esteem of the advisors in terms of child-parent relationships]. (Yayımlanmamış yüksek lisans tezi). Selçuk Üniversitesi, Sosyal Bilimler Enstitüsü, Konya.

Aykaç, M. (2019). Aile yaşam doyumuyla çocuk yaşam kalitesi arasındaki ilişki [The relationship between family life satisfaction and child quality of life] [Yayımlanmamış yüksek lisans tezi). Akdeniz Üniversitesi, Eğitim Bilimleri Enstitüsü, Antalya.

Aytekin, A., Arslan, N., \& Küçükoğlu, S. (2015). Hemşirelerin 3-6 Çocuklarının Yaşam Kalitesi ve Özbakım Becerilerinin İncelenmesi [Examining the Quality of Life and Self-Care Skills of Nurses' 3-6 Children]. Cumhuriyet Hemşirelik Dergisi, 3(2), 8-15.

Bekir, H., Şahin, H., \& Aydın, R. (2013). 4-7 Yaş Arası Sağlıklı Çocukların Ebeveyn Görüşlerine Göre Yaşam Kalitelerinin Belirlenmesi [Determining the Quality of Life of Healthy Children Between 4-7 Years Old According to Parents' Opinions]. Zeitschrift für die Welt der Türken/Journal of World of Turks, 5(3), 7-19.

Berman, A. H., Liu, B., Ullman, S., Jadbäck, I., \& Engström, K. (2016). Children's quality of life based on the kidscreen-27: child self-report, parent ratings and child-parent agreement in a Swedish random population sample. PloS one, 11(3), 1-15.

Chen, W., Niu, G. F., Zhang, D. J., Fan, C. Y., Tian, Y., \& Zhou, Z. K. (2016). Socioeconomic status and life satisfaction in Chinese adolescents: Analysis of self-esteem as a mediator and optimism as a moderator. Personality and Individual Differences, 95, 105-109. https://doi.org/10.1016/j.paid.2016.01.036

Crede, J., Wirthwein, L., McElvany, N., \& Steinmayr, R. (2015). Adolescents' academic achievement and life satisfaction: the role of parents' education. Frontiers in Psychology, 6, 52. https://doi.org/10.3389/fpsyg.2015.00052

Cummins, R. A. (2005). Moving from the quality of life concept to a theory. Journal of Intellectual disability research, 49(10), 699-706.

Çeçen Eroğlu, A. R., \& Dingiltepe, T. (2012). The Comparison of Adolescents from Single Parent Families and Intact Families in Terms of Life Satisfaction and Quality of Life. Ilkogretim Online, 11(4), 1077-1086.

Çivitci, A. (2009). İlköğretim öğrencilerinde yaşam doyumu: Bazı kişisel ve ailesel özelliklerin rolü [Life satisfaction in primary school students: the role of some personal and family traits]. Uludağ Üniversitesi Eğitim Fakültesi Dergisi, 22(1), 29-52. 
Demiriz, S., \& Ulutaş, İ. (2016). Çocuklar ne kadar mutlu? Bazı değişkenlere göre çocuklarda mutluluğun belirlenmesi [How happy are the children? Determining happiness in children according to some variables]. Adnan Menderes Üniversitesi Eğitim Fakültesi Eğitim Bilimleri Dergisi, 7(1), 16-24.

Dinisman, T., \& Ben-Arieh, A. (2016). The characteristics of children's subjective wellbeing. Social Indicators Research, 126, 555-569.

Erçetin, Ş. Ş., \& Açıkalın, Ş. N. (2020). Bilimsel araştırmalarda temel yaklaşımlar, araştırma modelleri ve desenleri [Basic approaches, research models and patterns in scientific research]. (Edt.: Ș. Ş. Erçetin). Araştırma teknikleri (s. 29-49). Ankara: Nobel Yayıncılık.

Erçetin, Ş. Ş., Potas, N., Açıkalın, Ş. N., Sarınç Ulaşlı, S., Çevik, M. S., Görgülü, D., ... \& Öz, Ö. (2020). Covid-19 Pandemisi'nin yaşam kalitesine etkisi [The effect of the Covid-19 Pandemic on the quality of life]. Retrieved from: http://www.iscass.org/uploads/img/covid-19pandemisinin-yasam-kalitesine-etkisi.pdf

Evirgen, N. (2010). Aile içi örüntülerin çocukların algıları açısından incelenmesi [Investigation of family patterns in terms of children's perceptions]. (Masters of art thesis, unpublished). Ankara Üniversitesi, Sosyal Bilgiler Enstitüsü, Ankara.

Goswami, H. (2012). Social relationships and children's subjective well-being. Social Indicators Research, 107, 575-588.

Hakvoort, E.M., Bos, H.M.W., Balen, F.V., \& Hermans, J.M.A. (2010). Family relationships and the psychosocial adjustment of school- aged children in intact families. The Journal of Genetic Psychology, 171(2), 182-201.

Huck, S. W. (2008). Reading statistics and research (fifth edition). New York: Addison Wesley Longman.

Kangal, A. (2012). Üniversite yaşam kalitesi ölçeğinin Türkçe uyarlaması: geçerlik ve güvenirlik çalışması [Turkish adaptation of the university quality of life scale: validity and reliability study]. E-International Journal of Educational Research, 3(1), 16-32

Karasar, N. (2009). Bilimsel araştırma yöntemi [Scientific research method]. Ankara: Nobel Yayın Dağıtım.

Kline, R. (2011). Convergence of structural equation modeling and multilevel modeling. In The SAGE handbook of innovation in social research methods (pp. 562-589). SAGE Publications Ltd, https://www.doi.org/10.4135/9781446268261

Koçtürk, N. (2020). Toplumsal cinsiyet ve çocuk istismarı ve ihmali. Ed. Ö. Haskan Avcl, Toplumsal cinsiyet: Psikolojik danışma ve rehberlikte güncel konular (sf. 357-391), Ankara: Nobel Akademik Yayıncılık.

Ma, C. Q., \& Huebner, S. (2008). Attachment relationships and adolescents' life satisfaction: Some relationships matter more to girls than boys. Psychology in the Schools, 45(2), 177190.

Mahase, E. (2020). China coronavirus: WHO declares international emergency as death toll exceeds 200. BMC, 368, doi: 10.1136/bmj.m408

MEB (2020a). Bilim ve Sanat Merkezleri yönergesi [Science and Art Centers directive]. https://orgm.

meb. gov.tr/meb_iys_ 
dosyalar/2015_09/18101802_bilimvesanatmerkezleri ynergesi.pdf (Date accessed: 05.10.2020).

MEB (2020b). Milli Eğitim İstatistikleri 2019/'20 [National Education Statistics 2019 / '20]. http://sgb. meb.gov.tr/meb_iys_dosyalar/2020_09/04144812_meb_istatistikleri_orgun _ egitim_2019_2020.pdf (Date accessed: 04.10.2020).

Migliorini, L., Tassara, T., \& Rania, N. (2019). A Study of Subjective Well-Being and Life Satisfaction in Italy: how are Children doing at 8 years of Age?. Child Indicators Research, 12(1), 49-69.

National Association for Gifted Children. (2020). COVID-19 and anxiety in gifted children. Retrieved from: https://www.nagc.org/blog/covid-19-and-anxiety-gifted-children

Neuman, W. (2014) Social research methods: qualitative and quantitative approaches. Pearson, Essex, UK.

Nickerson, A.B., \& Nagle, R.J. (2004). The influence of parent and peer attachments on life satisfaction in middle childhood and early adolescence. Social Indicators Research, 66, 35-60.

Norusis, M. J. (2005). SPSS professional statistics user's manual. SPSS Inc. Chicago.

Özbey, S., Mercan, M., \& Alisinanoğlu, F. (2018). Okul öncesi eğitim kurumlarına devam eden 48-72 aylık çocukların yaşam kalitesi ile öz düzenleme becerileri arasındaki ilişkinin incelenmesi [Examination of the relationship between the quality of life of 48-72 month-old children attending pre-school education institutions and their selfregulation skills].JRES,5(2), 157-173.

Potas, N., \& Akçil Ok, M. (2020). Örnekleme yöntemleri [Sampling methods]. (Ed.: Ş. Ş. Erçetin). Araştırma teknikleri (s. 143-163). Ankara: Nobel Yayıncllık.

Prime, H., Wade, M., \& Browne, D. T. (2020). Risk and resilience in family well-being during the COVID-19 pandemic. American Psychologist, 75(5), 631-643. http://dx.doi.org/ $10.1037 / \mathrm{amp} 0000660$

Remuzzi, A., \& Remuzzi G. (2020). COVID-19 and Italy: what next? Health Policy, 395(10231), 1225-1228. Published Online, https://doi.org/10.1016/S0140-6736(20)30627

Sak, U. (2014). Üstün Zekâlllar [Gifted People]. Ankara: Vize Yayınları.

Shek, D.T.L. (2002). Family functioning and psychological well-being, school adjustment, and problem behaviour in Chinese adolescent with and without economic disadvantage. The Journal of Genetic Psychology, 163(4), 497-502.

Silverman, L. $\quad$ K. $\quad$ (2020). https://childdevelopmentinfo.com/ learning/gifted_children/\#gs.i2zh 4a (Date accessed: 06.10.2020)

Statham, J. \& Chase, E. (2010). Childhood wellbeing: A brief overview. Childhood Wellbeing Research Centre, 5,1-18.

Tabachnick, B. G. \& Fidell, L. S. (2012). Using multivariate statistics (6 $6^{\text {th }}$ Ed.). Needham Heights, MA: Allyn and Bacon.

Ministry of Health, Turkey (2020). https://covid19.saglik.gov.tr/TR-66935/genelkoronavirus-tablosu. html (Date accessed:30.09.2020) 
Terry, T. \& Huebner, E. S. (1995). The Relationship between Self - Concept and Life Satisfaction in Children. Social Indicators Research, 35(1), 39-52.

Tümer, T. (2018). 9-11 yaş arası çocukların yaşam kalitesinin aile işlevselliği ve sosyodemografik değişkenler açısından incelenmesi [Examining the quality of life of children aged 9-11 in terms of family functionality and socio-demographic variables] (Yayımlanmamış yüksek lisans tezi). Ege Üniversitesi, Sosyal Bilimler Enstitüsü, İzmir.

Türütgen Şimşek, Z. (2001). Yaşam kalitesi ölçeğinin psikometrik değerlendirilmesi [Psychometric evaluation of the quality of life scale]. Toplum ve Sosyal Hizmet Dergisi, 12(2), 3-30.

Veenhoven, R. (2000). The four qualities of life. Journal of Happiness Studies, 1(1), 1-39.

Ünüvar, P., Çalışandemir, F., Tagay, Ö. \& Amini, F. (2015). Okul öncesi dönem çocuklarının mutluluk algısı (Türkiye ve Afganistan Örneği) [Preschool children's perception of happiness (Turkey and Afghanistan Example)]. Mehmet Akif Ersoy Üniversitesi Eğitim Fakültesi Dergisi, 34, 1-22.

World Health Organization. (WHO, 2020). https://www.who.int/emergencies/diseases/novel-coronavirus-2019?gclid $=\quad \mathrm{Cjw}$ KCAjw2dD7BRASEiwAWCtCbwbZPtGdpbyFeyS9gMhNyjQJRrWHYCnIjqbtAYOs0frvuv cJ-ki-2hoCfLcQAvDBwE (Date accessed: 30.09.2020)

Yağan-Güder, S., \& Güler-Yildiz, T. (2016). Okul öncesi dönemdeki çocukların toplumsal cinsiyet algllarında ailenin rolü. Hacettepe Üniversitesi Eğitim Fakültesi Dergisi, 31(2), 424-446.

Yılmaz, D. (2015). Üstün yetenekliler için psikolojik danışma ve rehberlik uygulamaları [Counseling and guidance services for gifted people]. Ankara: Nobel Akademik Yayıncllı.

Zu, Z. Y., Jiang, M.D., Xu, P.P., Chen, W., Ni, Q. Q., Lu, G. G. et al. (2020). Coronavirus Disease 2019 (COVID-19): A Perspective from China. Radiology, doi: 10.1148/radiol.2020200490. 
The ethics committee approval for this study was obtained from the Ethics Committee of the Rectorate of Ankara Hacı Bayram University, dated 29/09/2020 and numbered 10.

\section{Statement of Contribution of Researchers to the Article:}

1st author contribution rate: $20 \%$

2nd author contribution rate: $20 \%$

3rd author contribution rate: $20 \%$

4 th author contribution rate: $20 \%$

5th author contribution rate: $20 \%$

Conflict of Interest Statement:

There is no conflict of interest.

Statement of Financial Support or Acknowledgment:

No financial support was received from any institution for this study. We would like to thank those who contributed to the production of this work. 